\title{
Postharvest changes and respiratory pattern of bacuri fruit (Platonia insignis Mart.) at different maturity stages during ambient storage.
}

Gustavo Henrique de Almeida TEIXEIRA ${ }^{1}$, José Fernando DURIGAN ${ }^{1 *}$, Maria Aparecida LIMA ${ }^{1}$, Ricardo Elesbão ALVES², Heloísa Almeida Cunha FILGUEIRAS²

\begin{abstract}
Bacuri (Platonia insignis, Mart.) is one of the most important among Amazonian fruits. However, little is known about its postharvest physiology, such as maturity stages, changes during ambient storage, and respiratory pattern. Fruits were harvested at three maturity stages based on epicarp colour: dark green, light green, and turning (50\% yellow), in order to determine colour modification and respiratory pattern during ambient storage $\left(25.2^{\circ} \mathrm{C}, 75.1 \% \mathrm{RH}\right)$. Fruit of all maturity stages showed, after three days of harvest, a non-climacteric respiratory pattern, with turning fruit presenting the highest $\mathrm{CO}_{2}$ production rate until the fourth storage day $\left(177.63 \mathrm{mg} \cdot \mathrm{CO}_{2} \cdot \mathrm{kg}^{-1} \cdot \mathrm{h}^{-1}\right)$. Yellowing increased throughout storage as related to lightness, chromaticity, and hue angle reductions. Turning fruit can be stored at ambient conditions for up to 10 days without any loss in marketability.
\end{abstract}

\section{KEY WORDS}

Guttiferae, Tropical fruit, Non-climacteric, postharvest.

\section{Mudanças pós-colbeita e padrão respiratório de frutos de bacuri (Platonia insignis Mart.) em diferentes estádios de maturação durante o armazenamento no ambiente.}

\begin{abstract}
RESUMO
O bacuri (Platonia insignis, Mart.) é um dos mais importantes entre os frutos da Amazônia. Todavia, pouco se sabe sobre sua fisiologia pós-colheita, bem como, estádio de maturação, mudanças durante o armazenamento sob condições ambientais e padrão respiratório. Os frutos foram colbidos em três estádios de maturação baseados na coloração do epicarpo: verdeescuro, verde-claro e "de vez" (50\% amarelo), com o objetivo de se determinar as modificações de coloração e padrão respiratório durante armazenamento sob condições de ambiente $\left(25,2^{\circ} \mathrm{C}, 75,1 \%\right.$ UR). Os frutos de todos os estádios de maturação apresentaram, a partir do terceiro dia de colbeita, comportamento respiratório não climatérico, com os frutos "de vez" apresentando maior taxa de produção de $\mathrm{CO}_{2}$ até o quarto dia de armazenamento $\left(177,63 \mathrm{mg} \mathrm{CO}_{2} \cdot \mathrm{kg}^{-1} \cdot \mathrm{b}^{-1}\right)$. $\mathrm{O}$ amarelecimento aumentou durante o armazenamento e foi relacionado com a diminuição da luminosidade (L), cromaticidade e ângulo bue. Os frutos "de vez" podem ser armazenados sob condições de ambiente por até 10 dias sem nenbuma perda da qualidade comercial.
\end{abstract}

PALAVRAS-CHAVE

Guttiferae, fruta tropical, não climatérico, pós-colheita.

${ }^{1}$ Departamento de Tecnologia, FCAV/UNESP, Jaboticabal, Brazil.

${ }^{2}$ EMBRAPAAgroindústria Tropical, C.P. 3761, 60.511-110, Fortaleza, CE, Brazil.

"Corresponding author: Depto. Tecnologia, Faculdade de Ciências Agrárias e Veterinárias, Universidade Estadual Paulista, Via de acesso Paulo Donato Castellane, s/n, 14.884-900, Jaboticabal, SP, Brazil. Phone: 55 163209-2675 (246), Fax: 55 163202-4275, E-mail: jfduri@fcav.unesp.br 


\section{ACTA \\ AMAZONICA}

POSTHARVEST CHANGES AND RESPIRATORY PATTERN OF BACURI FRUIT

(PLATONIA INSIGNIS MART.) AT DIFFERENT MATURITY STAGES DURING AMBIENT STORAGE.

\section{INTRODUCTION}

The bacuri (Platonia insignis Mart.) is one of the most important among Amazonian fruits (Ferreira et al., 1987). This species is popular because of the creamy whitish pulp that envelops the seed and which has a distinct, strong, acid-sweet, agreeable flavour. Bacuri is increasing in popularity but demand has not yet exceeded supply. The fruit is obtained almost exclusively from wild or managed plants maintained on farms (Clement \& Venturieri, 1990).

Its natural distribution is found along the forest-savana transitional zone south of the Amazon forest, from the Atlantic to Paraguay (Clement \& Venturieri, 1990). Fouqué (1974) reported its origin as the rain forest of Guyana and the northern rain forest of Brazil. It occurs at low frequency ( 0.5 to 1 individual/ha) throughout this region, with occasional stands of 50-100 individuals per hectare, possibly due to Amerindian management.

The mature bacuri tree may attain 20 plus meters in height and 50 to $120 \mathrm{~cm}$ in diameter and is an element of the mid to upper canopy in these traditional forests (Calzavara, 1970). The cultivated plant, grown in a more open area, may attain $15-20 \mathrm{~m}$ in height, with a crown of $10-15 \mathrm{~cm}$ in diameter. The fruit is ovoid to subglobose, 7$15 \mathrm{~cm}$ long and $5-15 \mathrm{~cm}$ in diameter, weighting between 200 and $1000 \mathrm{~g}$. The rind is thick $(1-3 \mathrm{~cm})$, pale yellow to brownish yellow in colour, tough and somewhat elastic, and exudes a yellow latex when bruised (Fouqué, 1974; Calzavara, 1970).

Bacuri harvest season occurs from January to May, however the largest fruit production occurs between February and March. The fruit is collected 4 to 4.5 months after flowering, and a vigorous mature seedling tree will produce about 500 fruits per season (Calzavara, 1970), although some have been observed to produce up to 1000 .

With shorter trees obtained by grafting, studies are needed to establish the best maturity stage for bacuri harvest (Villachica et al., 1996). On the other hand, the best maturity stage can be based on colour modification during maturation and ripening, as colour changes have been used as a subjective harvest index (Pantastico et al., 1979a; Chitarra \& Chitarra, 1990).

In addition to maturity stage, respiratory pattern has great importance on determining fruit shelf life. Fruits which present high respiratory rates, such as bananas and avocados, tend to ripen faster, thus are more perishable (Tucker, 1993). On the other hand, among non-climacteric fruits, correlation exists between higher respiratory rates and shorter post harvest shelf life.

The objective of this work was to evaluate colour modification of bacuri fruit during ambient storage, as well as determine the respiratory pattern of this Amazonian fruit.

\section{MATERIAL AND METHODS}

\section{Fruit material}

Bacuri fruits were accessed from native trees in Matões, Maranhão State, Brazil. Fruit was harvested in three maturity stages based on epicarp colour; dark green (totally green), light green (25\% yellow) and turning (50\% yellow). Fruit was sent by express mail to Laboratório de Tecnologia dos Produtos Agrícolas of FCAV/UNESP, and was received in three days. Whereupon the fruit was immediately washed with tap water, dipped in sodium hypochloride solution at $100 \mathrm{~mL} . \mathrm{L}^{-1}$ for 5 minutes, and stored at room condition $\left(25^{ \pm} 2{ }^{\circ} \mathrm{C}\right.$ and $75 \pm 1 \%$ $\mathrm{RH})$, ambient condition, for eight days.

\section{Quality and colour evaluation}

Fresh mass loss was measured daily, weighing the fruit in a semi-analytic scale with 0.01 grams precision. Subjective visual appearance and colour evolution were evaluated using scores according to Teixeira (2000). For appearance: 1 , absence of browning symptoms; 2 , some brown spots; 3 , brown spots and light shrinkage; 4 , brown spots, severe shrinkage and rots, and 5, fruit totally brown and shrivelled. For colour: 1, fruit totally green; 2 , light green; 3 , beginning yellow colour; 4 , predominantly yellow and 5 , totally yellow. Colour was also determined using a Chromameter Minolta CR-200b, according to the system proposed by the Commission Internacionale de l'Eclaraige (CIE). Two points were marked on the equatorial region of the fruit, using three specimens per treatment, with three replications. The colour was expressed in lightness (L), chromaticity, and hue angle (McGuire, 1992).

\section{Chemical analysis}

Pulp was extracted and frozen at $-10{ }^{\circ} \mathrm{C}$ at the end of storage. Then it was homogenized and used for total soluble solids (TSS), titratable acidity (TA), and pH determination (A.O.A.C. 1995 - proc. 932-12, 942-15, 945-27, respectively), and ratio (TSS/TTA) as well.

\section{Respiration and gas analysis}

Respiration was determined daily using the groups of 3 fruit per each maturity stage, with 3 replications. The fruit was kept during one hour in a recipient hermetically closed (plastic jars $-2.0 \mathrm{~L}$ ) followed by determination of $\mathrm{CO}_{2}$ production into the recipient in $\mathrm{mg}$ of $\mathrm{CO}_{2} \cdot \mathrm{kg}^{-1} \cdot \mathrm{h}^{-1}$. The atmosphere composition inside the plastic jars was measured by injecting $0.3 \mathrm{~mL}$ gas samples in a gas chromatograph (Finningan 9001) equipped with Porapack-N and molecular sieve $(5 \mathrm{~A})$ columns, a thermal conductivity detector $\left(150{ }^{\circ} \mathrm{C}\right)$, and flame ionization detector $\left(150^{\circ} \mathrm{C}\right)$, using nitrogen as the carrier gas $\left(30 \mathrm{~mL} . \mathrm{min}^{-}\right.$ $\left.{ }^{1}\right)$. The data were integrated using a Borwin software.

\section{Statistical analysis}

The trial was conducted according to a split-plot design, with three treatments (main plot; maturity stages), eight withdraws (sub-plot; time) with three replications. The data were subjected to analysis of variance (ANOVA) using SISVAR statistical package. 


\section{ACTA \\ AMAZONICA}

POSTHARVEST CHANGES AND RESPIRATORY PATTERN OF BACURI FRUIT

(PLATONIA INSIGNIS MART.) AT DIFFERENT MATURITY STAGES DURING AMBIENT STORAGE.

\section{RESULTS AND DISCUSSION}

During ambient storage, fresh mass loss increased and was affected by the maturity stage. Dark green fruit lost more moisture, followed by light green and turning fruit (Figure 1). A loss in weight up to 5\% may be sufficient to promote wilt or shrinkage, affecting fruit and vegetable quality (Pantastico et al., 1979b). For bacuri, severe shrinkage was only observed for light green and dark green fruits at the end of the storage period, when they presented mass losses of $23.76 \%$ and $26.22 \%$, respectively. Higher weight losses for bacuri fruit at immature stages were also reported by Teixeira et al. (2001). This trend can be related to thick wax deposition on the exocarp, which provides good protection against excessive moisture loss (Mourão \& Beltrati, 1995).

Visual appearance was significantly affected by moisture loss (Figure 2b). Shrinkage was the main factor affecting appearance, however epicarp browning also contributed. Browning was the result of mechanical damage lesions occurring during harvest, which became worse throughout the storage. Light green and dark green fruits obtained the highest scores (worst appearance) following fresh mass loss trend. The appearance of turning fruit was significantly better after eight days of storage, obtaining the lowest scores.

Epicarp colour scores were higher $(\mathrm{P}<0.05)$ for the turning fruit group, which presented a colour completely yellow since the beginning of storage, three days after harvest (Figure 2a). Dark and light green fruit showed colour evolution, which from the sixth day did not differ from each other until the end of storage.

When CIE was used to measure fruit colour, it was observed that fruit became less bright and more yellow during storage (Figures 3a, b, c). Bright reduction was confirmed by lightness (L) reduction in turning and light green fruit, which presented values significantly higher than dark green (Figure 3a). Chromaticity was reduced during storage (Figure $3 b$ ), except for the dark green group, probably due to dehydration and lesions that occurred at harvest. These lesions browned the

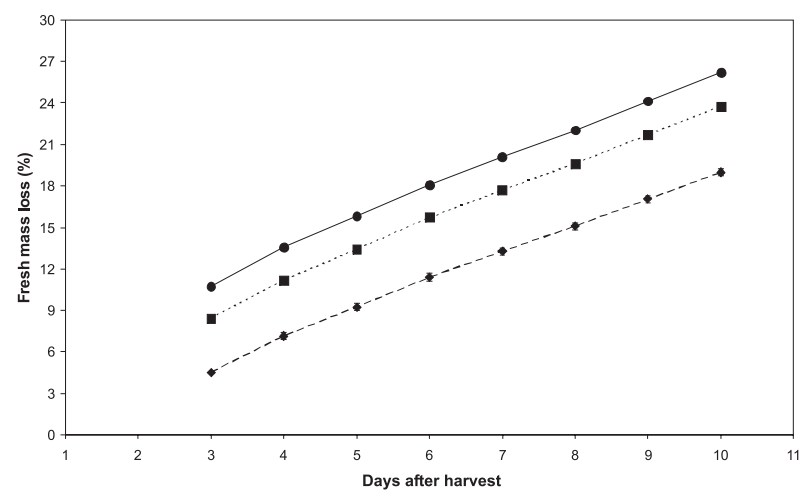

Figure 1 - Fresh mass loss (\%) of bacuri fruit stored under ambient conditions $\left(25.2^{\circ} \mathrm{C}, 75.1 \% \mathrm{RH}\right)$, in three stages of maturity, dark green $(\bullet)$, light green $(\mathbf{\square})$, and turning $(\bullet)$. Vertical bars denote SDs for means of 3 separate measurements. epicarp and also could have contributed to lightness reduction. Turning and light green fruit did not differ in chromaticity, however light green presented higher saturation than dark green, which was less colourful until the ninth storage day. Hue angle reduction confirms fruit yellowing during storage (Figure $3 \mathrm{c}$ ). Turning fruits did not present modification in this angle, thus, they were already yellow and therefore did not change colour during storage, which was in agreement with the observed epicarp colour scores (Figure 2a). The other two stages presented reduction in hue angle during storage, showing the transition from predominately green to predominately yellow by the tenth day of storage, when no statistical differences were observed.

No difference in the TSS content was observed, but observed differences were for TA, TSS/TA ratio, and pHbetween the maturity stages evaluated at the end of storage period (Table 1). Turning fruit was more mature, which was indicated by the lowest TA, highest ratio TSS/TTA and $\mathrm{pH}(\mathrm{P}<0.05)$. These results showed a good relation with epicarp colour scores at the end of storage (Figure 2a), where the fruits harvested in the turning stage presented the highest scores, with colour considered totally yellow, and therefore ripe. Besides the differences among maturity stages, the parameters evaluated were in agreement with values reported by Clement \& Venturieri (1990), Villachica et al. (1996), and Teixeira et al. (2001).
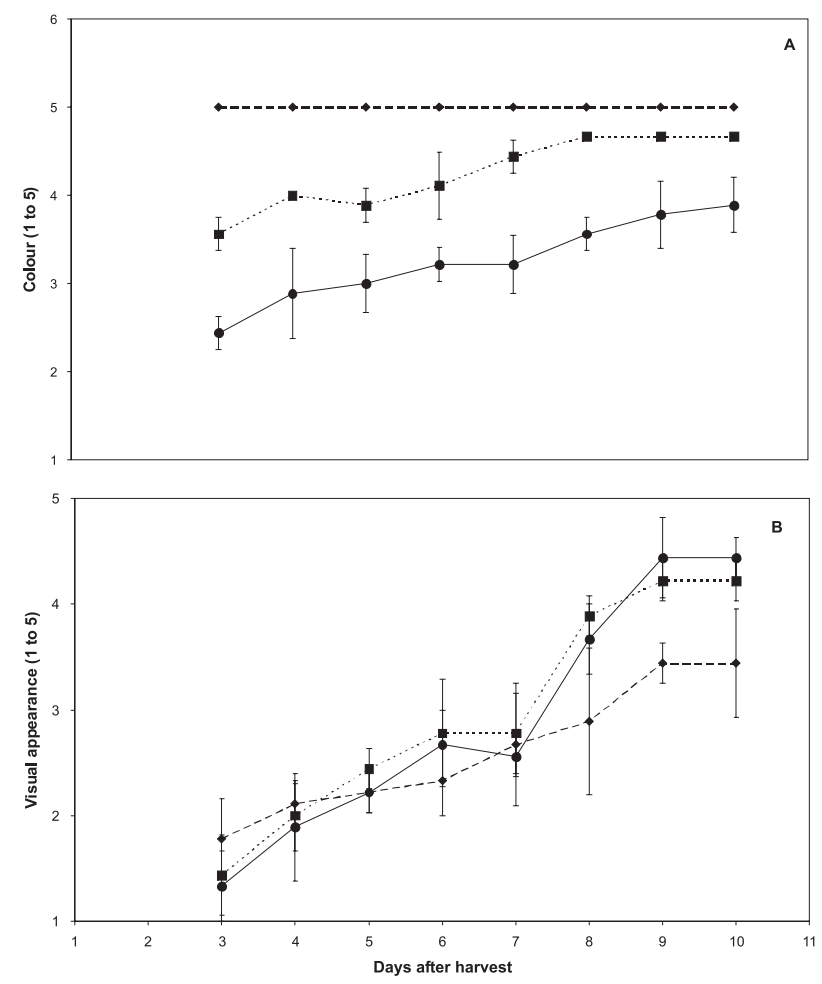

Figure 2 - Visual appearance (a) and epicarp colour (b) of bacuri fruit stored under ambient conditions $\left(25.2^{\circ} \mathrm{C}, 75.1 \% \mathrm{RH}\right)$, in three stages of maturity, dark green $(\bullet)$, light green $(\square)$, and turning $(\downarrow)$.Vertical bars denote SDs for means of 3 separate measurements. 


\section{ACTA AMAZONICA}
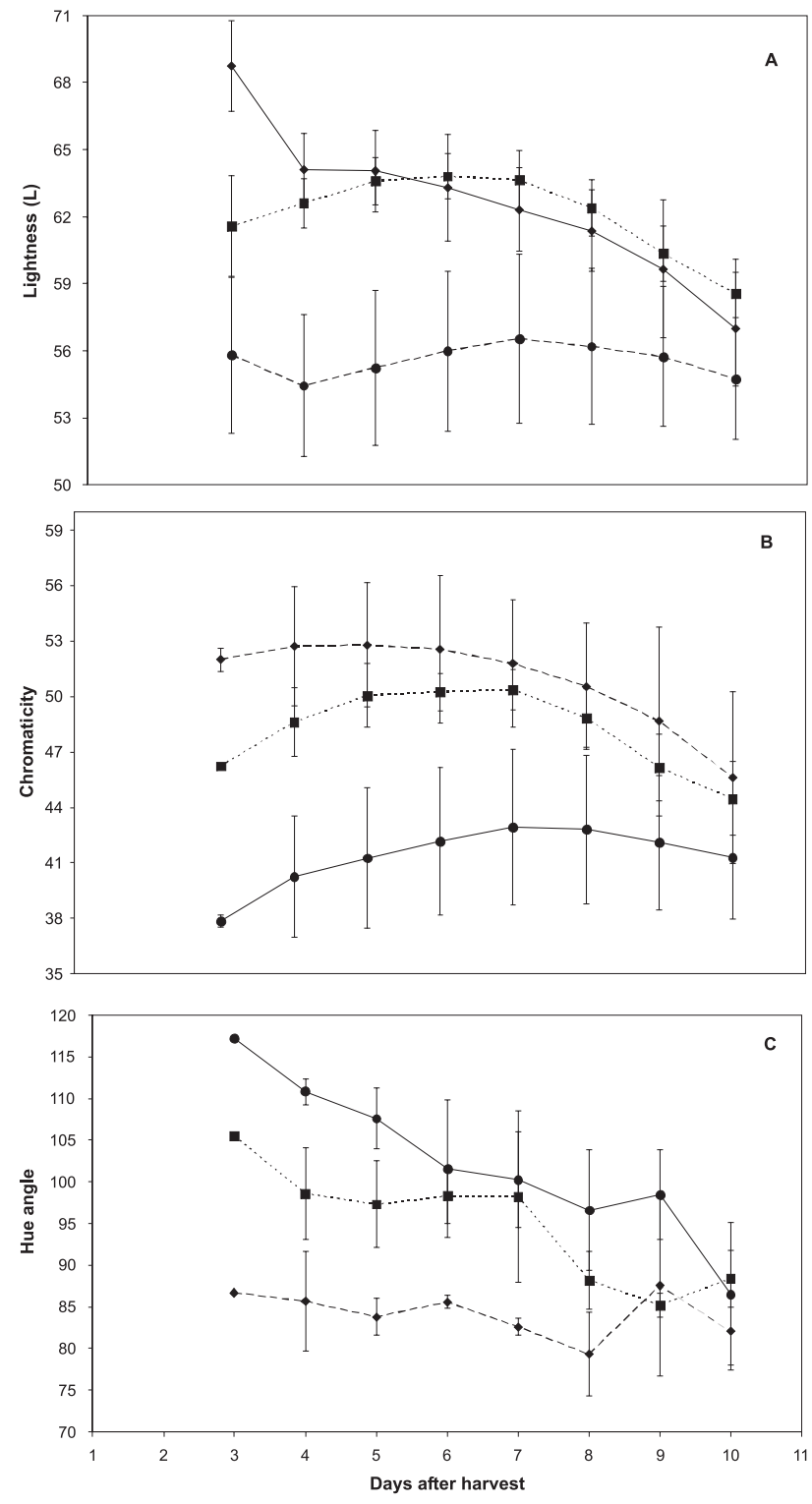

Figure 3 - Epicarp lightness - L* (a), chromaticity (b) and hue angle (c) by bacuri fruit stored under ambient conditions $\left(25.2^{\circ} \mathrm{C}, 75.1 \% \mathrm{RH}\right)$, in three stages of maturity, dark green $(\bullet)$, light green $(\square)$, and turning $(\diamond)$. Vertical bars denote SDs for means of 3 separate measurements.

Table 1 - Physical-chemical characteristics of bacuri fruit stored under ambient conditions $\left(25.2^{\circ} \mathrm{C}, 75.1 \% \mathrm{RH}\right)$, in three stages of maturity, after 10 days of storage.

\begin{tabular}{lcccc}
\hline \hline Maturity stage & TSS $^{\mathbf{A}}$ & TA $^{\mathbf{B}}$ & TSS/TA & PH \\
\hline Turning & $20.22 \mathrm{a}$ & $0.35 \mathrm{~b}$ & $58.98 \mathrm{a}$ & $3.25 \mathrm{a}$ \\
Light green & $19.08 \mathrm{a}$ & $0.50 \mathrm{ab}$ & $37.84 \mathrm{~b}$ & $3.02 \mathrm{~b}$ \\
Dark green & $18.81 \mathrm{a}$ & $0.64 \mathrm{a}$ & $29.87 \mathrm{~b}$ & $2.93 \mathrm{~b}$ \\
\hline F test & $2.28 \mathrm{~ns}$ & $15.13^{* *}$ & $21.03^{* *}$ & $13.01^{* *}$ \\
\hline \hline
\end{tabular}

${ }^{\mathrm{A}} \mathrm{TSS}=$ total soluble solids ( $\left.{ }^{\circ} \mathrm{Brix}\right){ }^{\mathrm{B}} \mathrm{BA}=$ titratable acidity (grams citric acid. $100 \mathrm{~g}^{-1}$ fresh pulp). Means followed by the same letter within the columns are not significant $(\mathrm{P}<0.01)$.
The respiratory rate of bacuri at three maturity stages is shown in Figure 4. Fruit respiration measured from the third day after harvest until the tenth day of ambient storage, followed the pattern attributed to non-climacteric fruit (Biale, 1964; Chitarra \& Chitarra, 1990; Tucker, 1993), showing a slow drift downwards after detachment from the parent plant. The respiratory rates, as measured three days after harvest, were considered as high as the strawberry which presents a very high metabolic activity (Biale, 1964; Kader, 1992). Turning fruit presented the highest respiratory rate $(\mathrm{P}<0.05)$ up to the fourth day of storage and did not differ between maturity stages after that, with the respiratory intensity decreasing significantly during storage.

According to Rhodes (1970) and Tucker (1993), fruit considered non-climacteric present gradual decline in the respiration rate, which is in agreement with the results found herein (Figure 4). On the other hand, the orange, lemon, and grapefruit which are "tree-ripened" fruits, as is bacuri (Calzavara, 1970; Villachica et al., 1996), when they are detached their respiration continues at a slowly declining rate. However, as the fruits arrived after three days of harvest, the climacteric rise in respiration might have occurred during this period. Biale \& Barcus (1970) studying some Amazonian fruits reported a climacteric rise in respiration for breadfruit from 40 to $180 \mathrm{~mL}$ $\mathrm{O}_{2} \cdot \mathrm{kg}^{-1} \cdot \mathrm{h}^{-1}$ in tow days period. Fruit from the Guttiferae botanic family, such as mangosteen (Garcinia mangustana L.), presented the climacteric peak by the tenth day of storage, although (Taylor, 1993).

Dull et al. (1967) have investigated the pattern of respiration in pineapple fruit picked at six stages and subsequently stored. They reported the fruit picked at the most immature stage presenting a rapid fall in respiration followed by a small rise and then a further rapid fall. The measurement of respiratory activity of bacuri fruit in this study was done at different maturity stages as indicated by colour differences. Thus, if the bacuri were a climacteric fruit, the characteristic upsurges in respiration rate would have been detected during the storage.

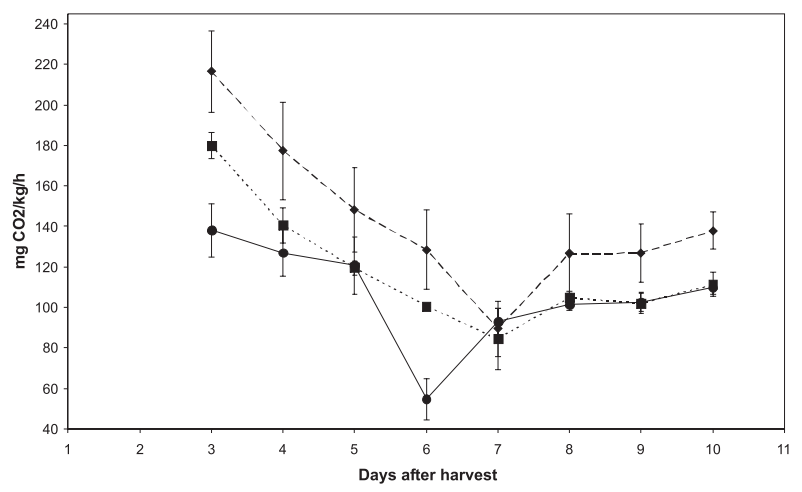

Figure 4 - Respiration rate of bacuri fruit $\left(\mathrm{mg} \mathrm{CO}_{2} \cdot \mathrm{kg}^{-1} \cdot \mathrm{h}^{-1}\right)$ stored under ambient conditions $\left(25.2^{\circ} \mathrm{C}, 75.1 \% \mathrm{RH}\right)$, in three stages of maturity, dark green $(\bullet)$, light green $(\boldsymbol{\square})$, and turning $(\bullet)$.Vertical bars denote SDs for means of 3 separate measurements. 


\section{CONCLUSIONS}

1) Colour was one important parameter when maturity stage was established based on bacuri epicarp colour.

2) Colour change was related to lightness (L), chromaticity and hue angle reduction.

3) Fruit of the maturity stages evaluated, from the third day after harvest, presented a gradual decline in $\mathrm{CO}_{2}$ rate production, indicating a non-climacteric respiratory pattern.

4) Turning fruit (50\% yellow) can be stored at ambient conditions for up to 10 days without any loss in marketability.

\section{ACKNOWLEDGEMENTS}

The authors would like to thank the Fundação de Amparo a Pesquisa do Estado de São Paulo (FAPESP Proc. 98/13237-9) for financial support, also European Union (INCO-DC/Contract ERBIC18CT970182).

\section{LITERATURE CITED}

Association of Official Analytical Chemists. 1995. Official Methods of Analysis of the Association of Official Analytical Chemists. A.O.A.C., Washington, p.910-928.

Biale, J.B. 1964. Growth, maturation, and senescence in fruits. Science, 146(3646):880-888

Biale, J.B; Barcus, D.E. 1970. Respiratory patterns in tropical fruits of the Amazon basin. Tropical Science, 7(2):93-104.

Calzavara, B.B.G. 1970. Fruteiras: abieiro, abricozeiro, bacurizeiro, biribazeiro, cupuaçuzeiro. IPEAN, Séries Culturas da Amazônia, Belém, p.63-68.

Chitarra, M.I.F.; Chitarra, A.B. 1990. Pós-colheita de frutos e hortaliças: fisiologia e manuseio. ESAL/FAEPE, Lavras, 289pp.

Clement, C.R.; Venturieri, G.A. 1990. Bacuri and cupuasu. In: Nagy, S.; Shaw, P.E.; Wardowski, W.F. (Eds.). Fruits of tropical and subtropical origin: composition, properties and uses. Florida Science Source Inc., Florida, p.179-192.

Dull, G.G.; Young, R.E.; Biale, J.B. 1967. Respiratory patterns in fruit of pineapple, Ananas comosus, detached at different stages of development. Physiologia Plantarum, 20(4):1059-1065.

Ferreira, F.R.; Ferreira, S.A.N.; Carvalho,J.E.U. 1987. Espécies frutíferas pouco exploradas com potencial econômico e social para o Brasil. Revista Brasileira de Fruticultura, 9(extra):11-22.

Fouqué, A. 1974. Espèces fruitières d'amérique tropicale. Fruits, 29(5):387-388.
Kader, A.A. 1992. Postharvest biology and technology: an overview. In: Kader, A.A. (Ed.). Postharvest technology of horticultural crops. University of California, Davis, p.15-201.

McGuire, R.G. 1992. Reporting of objective color measurements. HortScience, 27(12):1254-1255.

Mourão, K.S.M.; Beltrati, C.M. 1995. Morfologia dos frutos, sementes e plântulas de Platonia insignis Mart. (Clusiaceae). I. Aspectos anatômicos dos frutos e sementes em desenvolvimento. Acta Amazonica, 25(1/2):11-31.

Pantastico, ER.B.; Subramanyam, H.; Bhatti, M.B.; Ali, N.; Akamine, E.K. 1979a. Indices para Cosecha. In: Pantastico, ER.B. (Ed.). Fisiologia de la postrecoleccion manejo y utilizacion de frutas y hortalizas tropicales y subtropicales. Compañia Editorial Continental, Mexico, p.375-405.

Pantastico, ER.B.; Chattopadhyay, T.K.; Subramanyam, H. 1979b. Almacenamiento y operaciones comerciales de almacenaje. $I n$ : Pantastico, ER.B. (Ed.). Fisiologia de la postrecoleccion manejo $y$ utilizacion de frutas y bortalizas tropicales y subtropicales. Compañia Editorial Continental, Mexico, p.375-405.

Rhodes, M.J.C. 1970. The climateric and ripening of fruits. In: Hulme, A.C. (Ed.). The biochemistry of fruits and their products. Academic Press Inc., London, p.521-533.

Taylor, J.E. 1993. Exotics. In: Seymour, G.B.; Taylor, J.E.; Tucker, G.A. (Eds.). Biochemistry of fruit ripening. Chapman \& Hall, Cambridge, p.151-177.

Teixeira, G.H.A. 2000. Frutos do bacurizeiro (Platonia insignis Mart.): caracterização, qualidade e conservação. Dissertação de Mestrado, Faculdade de Ciências Agrárias e Veterinárias/ Universidade Estadual Paulista, Jaboticabal, São Paulo. 106pp.

Teixeira, G.H.A.; Durigan, J.F.; Alves, R.E.; Filgueiras, H.A.C.; Moura, C.F.H. 2001. Almacenamiento de los frutos de bacuri en tres estados de maduración: evaluación fisica, química y del color. Revista Iberoamericana de Tecnología Postcosecha, 3(1):39-47.

Tucker, G.A. 1993. Introduction. In: Seymour, G.B.; Taylor, J.E.; Tucker, G.A. (Eds.). Biochemistry of fruit ripening. Chapman \& Hall, Cambridge. p.1-51.

Villachica, H.; Carvalho, J.E.U.; Muller, C.H.; Diaz, S.; Almanz, C. 1996. Frutales y hortalizas promisorios de la Amazonia. Tratado de Cooperacción Amazonica, Lima. p.50-55.

RECEBIDO EM 12/11/2003
ACEITO EM 26/11/2004 
